\title{
A review of rice field ostracods (Crustacea) with a checklist of species
}

\author{
Robin J. SMITH,${ }^{*}$ Dayou ZHAI, ${ }^{2}$ Sukonthip SAVATENALINTON,${ }^{3}$ Takahiro KAMIYA, ${ }^{4}$ Na YU ${ }^{5}$ \\ ${ }^{1}$ Lake Biwa Museum, Oroshimo 1091, Kusatsu, Shiga Prefecture 525-0001, Japan; ${ }^{2}$ Yunnan Key Laboratory for Palaeobiology, \\ Yunnan University, No. 2 Cuihubei Road, Kunming 650091, China; ${ }^{3}$ Department of Biology, Faculty of Science, Mahasarakham \\ University, Mahasarakham 44150, Thailand; ${ }^{4}$ College of Science and Engineering, School of Natural System, University of \\ Kanazawa, Kakuma, Kanazawa 920-1192, Japan; ${ }^{5}$ Laboratory of Aquaculture Nutrition and Environmental Health (LANEH), School \\ of Life Sciences, East China Normal University, No. 500 Dongchuan Road, Shanghai 200241, China \\ *Corresponding author: robin-james-smith@biwahaku.jp
}

\begin{abstract}
Ostracods are very common in rice fields and they can have a significant influence on the rice field ecosystem. They can reach very high densities, often higher than other meiofauna, and their activities can have both positive and negative effects on rice harvests. They directly affect nutrient recycling through excretion, and indirectly by physically disturbing the soil and releasing minerals, thus improving rice growth. On the other hand, ostracods grazing on nitrogen-fixing cyanobacteria potentially reduce rice yields. Rice is a primary staple food for over half of the world's population, and therefore ostracods can have a significant impact on human food supply. The origin of the rice field ostracod fauna is poorly known, but many rice field ostracods are considered invasive, especially in southern Europe, and from rice fields they have the potential to spread to surrounding natural habitats. Despite their invasive potential and ecological effects on the rice field ecosystem, very little is known about the diversity, ecology and impacts of rice field ostracods in many rice-producing countries. One hundred and ninety-two named ostracod species/subspecies have been reported from rice fields in 26 countries and states worldwide in the published literature; for over three-quarters of riceproducing countries, no data are readily available, and for most of the countries that have available data, diversity is clearly underreported. Most species that have been documented from rice fields belong to the Cyprididae (78\%), a family that makes up approximately $43 \%$ of the $2500+$ non-marine ostracod species. A further six families (Candonidae, Darwinulidae, Entocytheridae, Ilyocyprididae, Limnocytheridae and Notodromadidae) form the remainder of rice field ostracods. Twenty-two percent of the species reported from rice fields are sexually reproducing, $18 \%$ have mixed reproduction, but are mostly asexual, and for $60 \%$ males are unknown, and are probably entirely asexually reproducing species. This review and checklist of rice field ostracods are presented to facilitate further research on this group in rice field habitats, research that is crucial for food security in many regions
\end{abstract}

Key words: Ostracoda; agriculture; Oryza sativa; invasive species; food security.

Received: April 2017. Accepted: July 2017.

\section{INTRODUCTION}

Rice is a primary staple food for over half of the world's population, and correspondingly rice production has been called the most important economic activity on earth (Maclean et al., 2002). Rice fields cover 163 million hectares, accounting for $11.7 \%$ of the world's arable land (Food and Agriculture Organization of the United Nations Statistics Division 2016). They are found in 116 countries worldwide, but production is concentrated in relatively few countries. The twenty countries with the largest areas of rice fields account for $92.9 \%$ of the total area, and $88.9 \%$ of all rice fields occur in Asia (Food and Agriculture Organization of the United Nations Statistics Division, 2016) (Fig. 1).

There are several different types of rice growing environments, including rain-fed lowland, deepwater, upland, and tidal wetlands environments, but the majority of rice is grown in irrigated paddy fields (Khush 1984).
Molecular evidence indicates that farming for asiatic rice originated from a single domestication event $\sim 8200$ 13,500 years ago in the Yangtze Valley of China (Molina et al., 2011), and spread to different regions from there over time spans of thousands of years. Although a young habitat, many species of flora and fauna have colonized rice fields; ostracods, copepods, cladocerans, aquatic insects, insect larvae, rotifers, molluscs, oligochaetes and nematodes are the dominant groups of aquatic invertebrates (Roger, 1996). Ostracods are very common in rice fields, and are often the most abundant group, with densities reported up to 98,000 ind $\mathrm{m}^{2}$ (Simpson et al., 1994; Roger, 1996). They can have a direct effect on the growing rice, more so than other micro-crustaceans (Roger, 1996), and considering the economic and social importance of rice cultivation, ostracods have a significant, but often underappreciated, impact on humans.

Ostracods (Class Ostracoda) are a diverse group of small aquatic crustaceans (Fig. 2). Their most distinctive 
feature is their calcitic carapace; a hard, bivalved, hinged shell that can entirely cover and protect the non-mineralized body parts and appendages. The lengths of ostracods reported from rice fields range from less than 0.5 $\mathrm{mm}$ (e.g. 0.36-0.45 $\mathrm{mm}$ for Limnocythere stationis Vávra, 1891) through to $7 \mathrm{~mm}$ (Madagascarcypris voeltzkowi (G.W. Müller, 1898)), but most are about 0.6 $\mathrm{mm}$ to $2.5 \mathrm{~mm}$ in length.

Studies on the rice field ostracod faunas in particular regions are very patchy (Fig. 1). The rice field ostracod faunas of Italy, Japan and some South East Asian countries are relatively well documented, mainly due to the work of a small number of researchers (Italy: Moroni, 1967; Ghetti, 1973; McKenzie and Moroni, 1986; Rossi et al., 2003. Japan: Okubo, 1972a, 1972b, 1972c, 1972d, 1973a, 1973b; 1974a, 1974b, 1975, 1990a, 1990b, 2004. Thailand: Savatenalinton and Martens, 2008, 2009, 2010; Savatenalinton and Suttajit, 2016. Indonesia, Malaysia and the Philippines: Victor and Fernando, 1980, 1981a, 1981b, 1981c, 1981d, 1981e, 1981f, 1981g, 1982). For some countries, notably China and India, which combined account for $45 \%$ of the global area of rice fields, the fauna is poorly known. For many major rice-producing countries we could find no records of ostracods from rice fields, with only two species reported from Africa (Madagascar), five from North America, and six from South America (Fig. 1).
Considering the importance of rice as a major staple foodstuff, the very large areas of arable land that rice fields cover, and the potential impacts of ostracods on growing rice (and hence human food supply), the lack of information on rice field ostracods in many areas is surprising. This dearth of studies is perhaps because ostracods are generally considered to be a difficult taxonomic group to work on, and ostracod researchers have tended to be based in western countries with few or no rice fields. Additionally, researchers have tended to focus on natural environments, such as lakes, river systems and groundwaters, and because rice fields are artificial environments, they could be incorrectly seen as less significant or less 'interesting' in terms of biodiversity. In China, ostracods have mostly featured in geological and palaeoenvironmental studies (Hou et al., 1978; Zheng, 1983; Huang, 1984; Mischke and Wünnemann, 2006; Zhu et al., 2010; Zhai et al., 2011), with work on living ostracods mainly restricted to lacustrine environments to facilitate the interpretation of fossil assemblages (Mischke et al., 2007; 2010). More research is crucial if we are to understand the biodiversity and ecology of ostracods in rice fields, and their potential to become invasive species and their associated economic impacts. This review is to facilitate a better understanding of ostracods in rice fields, and a global checklist of ostracod species reported from rice fields is presented.

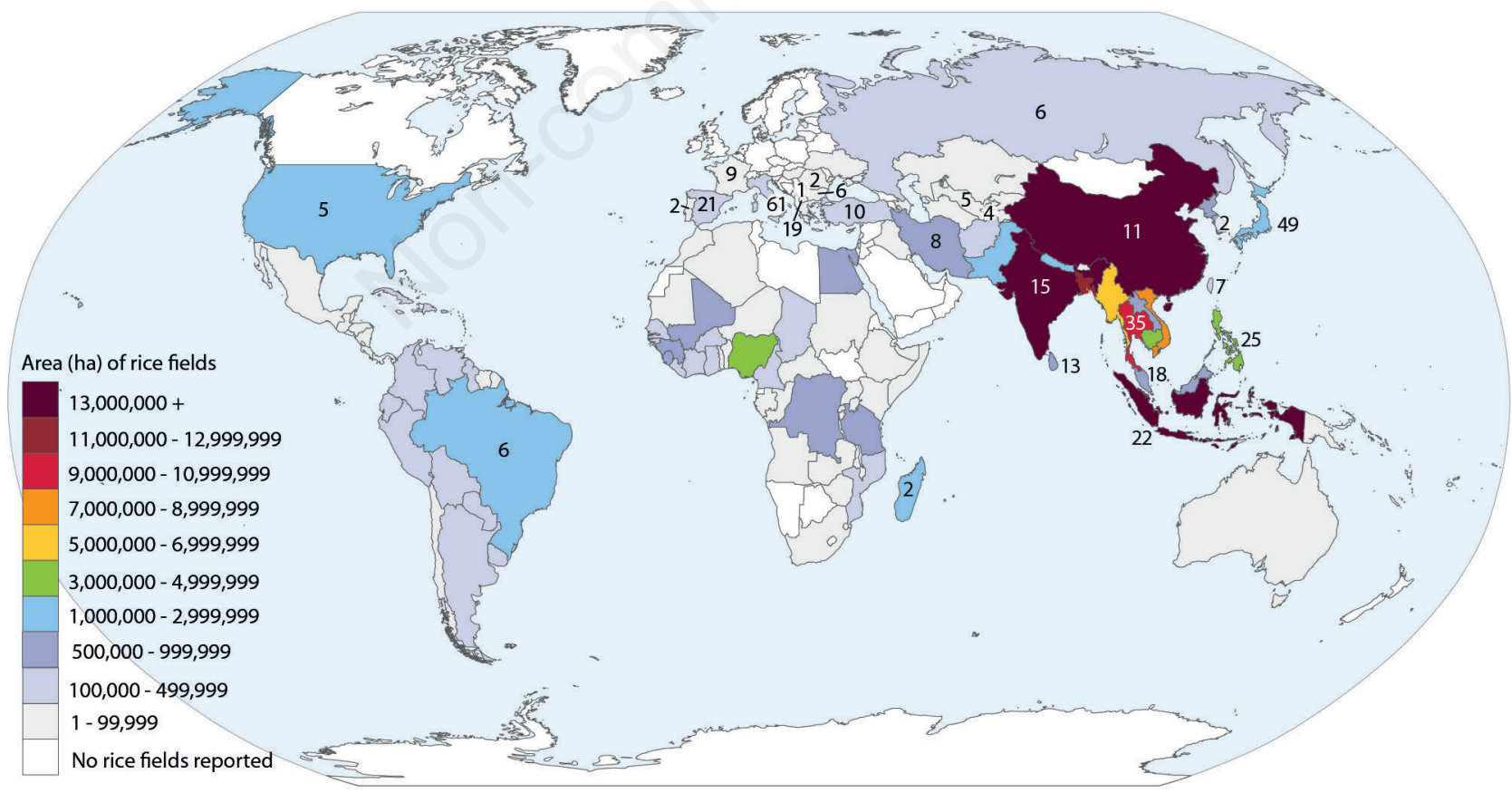

Fig. 1. Areas of rice fields worldwide (shaded), and the number of ostracod species reported from rice fields in each country and state. For many rice-producing countries no ostracods have been reported from rice fields. For additional details, see Appendix. Note that India and China combined account for $45 \%$ of the global area of rice fields. Rice production data from the Food and Agriculture Organization of the United Nations Statistics Division for the year 2014. 


\section{THE RICE FIELD HABITAT}

Rice fields are harsh environments for aquatic faunas. Temperature fluctuations, especially in rice fields in temperate regions, can be over $20^{\circ} \mathrm{C}$ in a 24-hour period, and maximum temperatures can reach $40^{\circ} \mathrm{C}$ (Yoshida, 1981; Grant et al., 1986). The growth of algae and aquatic plants cause marked diurnal changes in $\mathrm{pH}$ and oxygen levels (Maclean et al., 2002). During times of algal blooms diurnal changes in $\mathrm{pH}$ from neutral to 9.5 are not uncommon, reaching as high as 11 , and the standing water in rice fields can become oversaturated in oxygen (Forés and Comín, 1992; Roger, 1996; Maclean et al., 2002). Methane emissions from rice fields also show diurnal changes, positively correlated to soil temperatures (Grant et al., 1986). The most extreme diurnal variations in water chemistry and temperature tend to occur during the beginning of the crop cycle after the fields have been fertilized, which causes algal blooms, and later decrease when the water is shaded by the canopy of the rice plants (Watanabe and Roger, 1985; Roger, 1996; Fernández-Va- liente and Quesada, 2004). Ultra violet radiation is high, especially in the early part of the growing season before the rice plants produce a shading canopy. The application of pesticides and herbicides can have a negative effect on their aquatic inhabitants, and ploughing, planting, weeding, and harvesting of rice fields are high impact activities that can dramatically disturb the rice field ecosystem (Grant et al., 1986). The growing rice changes the physical and chemical characters of the rice field, thus the ecosystem dramatically changes through the rice-growing cycle (Forés and Comín, 1992; Fernández-Valiente and Quesada, 2004). The duration of the aquatic phase of rice fields varies considerably depending on the region, and also year by year, and the physical nature of the water varies through the rice cycle, from flowing, stagnation, and finally a drying out phase (Bambaradeniya and Amarasinghe, 2003). In some warmer regions, two or three crops a year are produced (Van Arsdale and Lewis, 1995), while in cooler areas a yield of one crop a year results in a longer fallow period of up to eight months. Brazilian rice fields typically have a fallow stage lasting

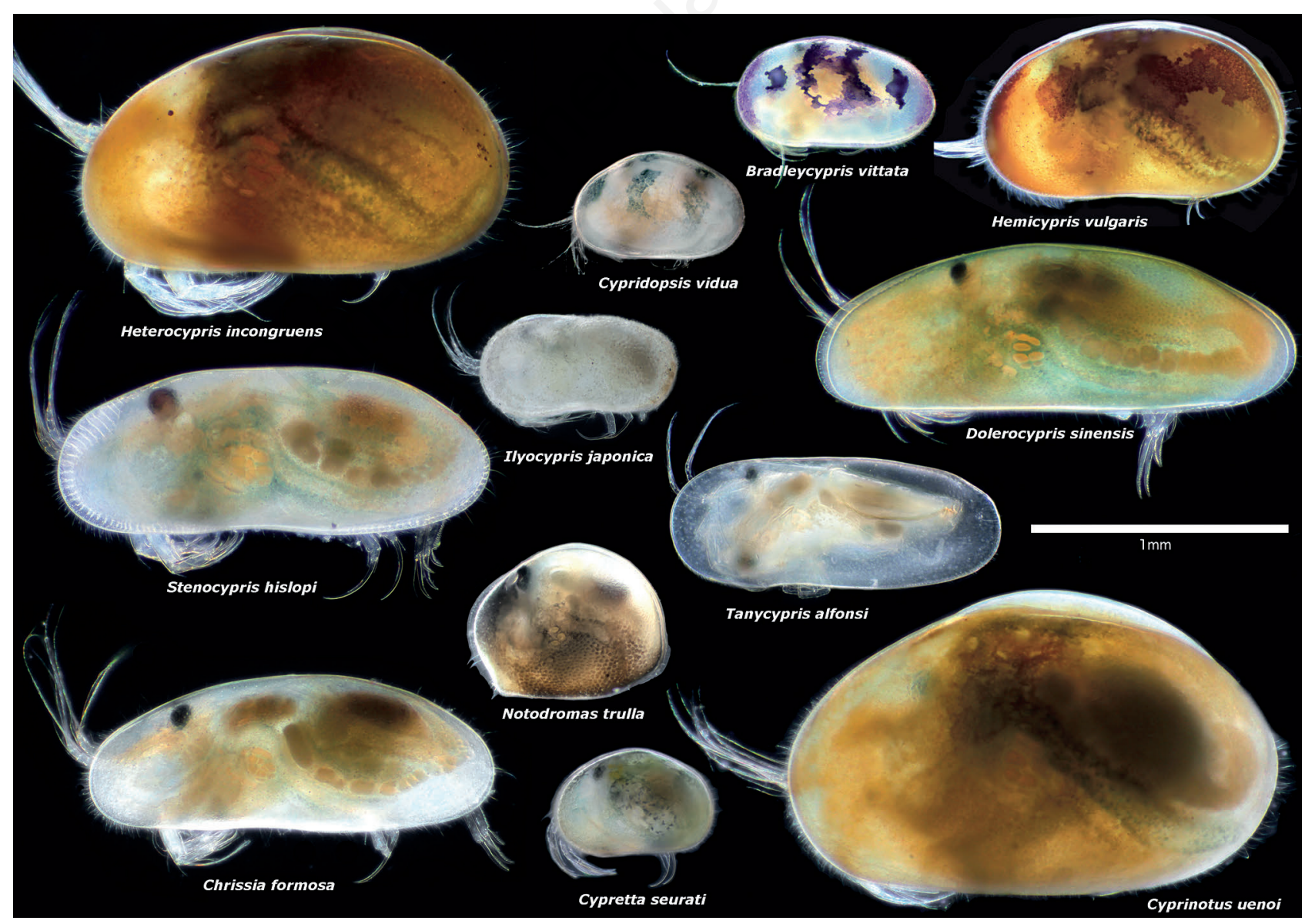

Fig. 2. Some ostracod species reported from rice fields. Left lateral views. 
two years to restore soil fertility, increase soil organic content and suppress weeds (Stenert et al., 2010).

If a species can tolerate the harsh and variable conditions of rice fields, there are considerable benefits. For microfauna, they are usually rich in food resources, such as algae and organic detritus, and they tend to lack larger predators, such as fish, although in some parts of the world, rice fields are used as fish nurseries (Fernando, 1996; Miao, 2010). Covering $11.7 \%$ of all arable land, they are also a very large habitat to exploit, and the movement of people, machinery and rice seedlings between fields are useful dispersal mechanisms. Ostracods are ideally suited to exploit rice fields, which is why they are often the dominant group in the rice field environment (Roger, 1996). Many rice field ostracods have desiccation-resistant eggs (Horne and Martens, 1998; Stenert et al., 2010), their carapaces help to retain moisture during periods of drought and protect them from UV radiation (Van den Broecke et al., 2012), they have a short life cycle, and they consume organic detritus, algae and cyanobacteria, all prolific in rice fields.

Because rice fields are very variable in location and farming technique, the conditions of rice fields can vary considerably. Khush (1984) listed 18 main types of rice growing environments, including four types of upland rice environments that lack standing water. Other types include rain-fed lowland (five types), deepwater (two types), tidal wetlands (four types), and irrigated (three types) environments. At a smaller scale, differences in soil types, water chemistry, climate, altitude, and local farming practices also increase the variety of rice growing environments, and such factors can vary over a small area. For most studies concerning ostracods in rice fields, little or no data are available about the type of rice growing environments, so it is not possible to correlate species composition with other factors. For example, two typical spring-dwelling ostracod species [Dolerocypris ikeyai Smith and Kamiya, 2006 and Eucypris pigra (Fischer, 1851)] have been reported from rice fields in Japan (Tanaka et al., 2015), and this maybe because the rice fields were filled by local spring water. Additionally, rice growing areas not only have the rice field habitat itself, but a mosaic of interconnected environments, such as the surrounding levees, and connected irrigation ditches, canals, ponds and reservoirs (Bambaradeniya and Amarasinghe, 2003), which can serve as important habitats for aquatic faunas, including ostracods; these too can vary considerably between areas. Finally, fields used to grow rice can be temporally re-purposed for other crops that don't require standing water during growth. For example, fields used for rice in Japan are also used for soya or wheat during some years. This has a further impact on the aquatic rice field fauna, and only those species with eggs that can be torpid for substantial periods of time, or those transported into the rice fields from surrounding habitats (e.g., via irrigation water) will colonize the field if it is used for rice again.

\section{ECOLOGY OF OSTRACODS IN RICE FIELDS}

\section{Utilization of the rice field habitat}

Ostracods live on and in the surface-oxidized soil layer of rice fields, and nektobenthic species additionally utilize the floodwater. The family Notodromadidae contains species that spend considerable amounts of time as neuston, hanging upside down from the water surface, typically in small shallow habitats, including rice fields. The oxidized soil layer is a photic aerobic environment with a positive redox potential and is microbiologically very active. Carbon dioxide, nitric oxide, ferric oxide and sulphate levels are stable, and algae and aerobic bacteria predominate (Roger, 1996). The depth of the oxidized layer is typically between 2 and $20 \mathrm{~mm}$, and is dependent not only on the concentration of dissolved oxygen in the water and reducing capacity of the soil, but also on the activities of benthic and interstitial faunas (Roger, 1996), which include the exploits of ostracods. The activities of benthic invertebrates directly affect nutrient recycling through excretion, and indirectly by physically disturbing the soil and releasing minerals (Roger, 1996). The extent to which ostracods contribute to nutrient recycling in rice fields is unknown, but is likely to be significant considering their high densities and near ubiquitous presence. The surface-oxidized soil layer is in continuous exchange with the water above and the two can be seen as a continuous environment; nektobenthic ostracod species mirror this continuum by constantly moving from the soil layer to the floodwater.

\section{Densities}

Ostracods have been reported to often be the most abundant aquatic invertebrate group in surveys of rice fields (Simpson et al., 1994; Roger, 1996;). Simpson et al. (1994) documented ostracod densities ranging from 0 through to 98,000 ind $\mathrm{m}^{2}$, with a mean of 6000 for rice fields in the Philippines. Other studies have recorded ostracod densities of 10 to $20,000 / \mathrm{m}^{2}$ in the Philippines (Grant et al., 1986), and 300 to $37,000 / \mathrm{m}^{2}$ in Malaysian rice fields (Lim and Wong, 1986). In Philippine rice fields ostracods appear early in the crop cycle, after mosquito and chironomid larvae, but before copepods and cladocerans (Roger et al., 1994b; Simpson et al., 1994), and peaking at about 22 days after rice transplanting (Grant et al., 1986). This is attributed to the blooming of phytoplankton and algae on the soil surface after fertilizers have been applied. Where no fertilizers are applied, or if fertilizers are deep-placed in the soil, rapid increases of ostra- 
cods are not seen (Simpson et al., 1994; Roger, 1996). Another study focussing on Spanish rice fields noted that ostracods are most abundant in the last phases of rice cultivation (Forés and Comín, 1992). Taniguchi et al. (1997) estimated that epibiotic bacteria on high densities of Cypretta sp. accounted for 1 to $10 \%$ of the total bacteria in the water of the rice field. Ostracods have been reported to appear more frequently in rice fields that have had compost applied, compared with rice fields with no compost applied (Yamazaki et al., 2001). Competition between ostracods and chironomid larvae may be responsible for the decline in the latter during the rice growing period (Simpson et al., 1994).

\section{Successions of species through the crop cycle}

Successions of ostracod species through the crop cycle undoubtedly differ depending on numerous factors, and could have an impact on the growing rice, but few studies have addressed this aspect (Ghetti, 1973). For invertebrates generally, grazers are dominant in the early part of the crop cycle, but later organic detritus accumulates, and this supports benthic filter feeders and deposit feeders (Roger, 1996). A similar scenario could potentially occur with ostracods, but detailed diets and feeding behaviours of most ostracod species are poorly known, especially for those in rice field habitats. Other factors, such as tolerance to diurnal changes in water temperatures and chemistry, and reproduction rates could also play a significant role in succession of ostracod species in rice fields. Ghetti (1973) noted the abundances of 55 species in 17 rice fields over the rice growing season, as well as recording water depth, temperature and oxygen levels. Heterocypris incongruens (Ramdohr, 1808) tended to appear early in the growing season in large numbers and tail off towards the end. Other species, such as Cypridopsis vidua (O. F. Müller, 1776), tended to appear later in the growing season. Many species appeared in smaller numbers for short periods in only a small number of rice fields, and some showed numerous increases and decreases of populations through the growing season.

\section{Feeding}

Most free-living freshwater ostracods consume mainly algae, cyanobacteria and organic detritus, but have also been reported to feed on bacteria, fungi, protozoans, plants and pollen, fallen leaves, rotifers, oligochaetes, nematodes, copepods, cladocerans, chironomids, mosquito larvae, gastropod larvae, amphibian eggs, fish fry, assorted dead animals and even other ostracods, including individuals of the same species (Liperovskaya, 1948; De Deckker, 1983; Strayer, 1985; Campbell, 1995; Fryer, 1997; Smith and Delorme, 2010; Gray et al., 2010; Ottonello and Romano, 2011; Rossi et al., 2011). Ostra- cods are not widely reported to directly feed on rice plants, but in experiments, ostracods have been documented damaging the roots of two-week old rice seedlings suspended in water (Barrion and Litsinger, 1984).

The consumption of cyanobacteria by ostracods is the most researched aspect of ostracod ecology in rice fields. Of the grazers (including cladocerans, copepods, rotifers, chironomid and mosquito larvae, ostracods and gastropods) that have the biggest impact on the photosynthetic biomass of rice fields, ostracods and gastropods have been reported to be particularly important in limiting the growth of nitrogen-fixing cyanobacteria (FernándezValiente and Quesada, 2004; Grant et al., 1986). This grazing of cyanobacteria by ostracods (and other invertebrates) can therefore have a deleterious effect on the growing rice (De, 1939; Wilson et al., 1980; Osa-Afiana and Alexander, 1981; Grant et al., 1983a; 1985; Roger, 1996; Fernández-Valiente and Quesada, 2004). Nitrogenfixing cyanobacteria become dominant in the rice field ecosystem after the initiation of the panicles of the rice plant through to harvest (Fernández-Valiente and Quesada, 2004). The grazing on non-colonial nitrogenfixing cyanobacteria may cause mucilaginous colonial forms, which are less susceptible to grazing, to become dominant, but mucilaginous cyanobacteria are less active at fixing nitrogen (Roger and Kurihara, 1991; Roger et al., 1994a). Measurements of the rates of grazing of the ostracod Heterocypris carolinensis (Ferguson, 1958) on cyanobacteria ranged from 32.2 to $75.8 \mu \mathrm{g}$ dry wt/ostracod per day depending on whether the ostracods had been starved or not before the experiments; ostracod densities did not significantly influence grazing rates unless very high (i.e., 560 individuals per $60 \mathrm{~mL}$ of water) (Grant $e t$ al., 1983a). Declines in the blooms of cyanobacteria are attributed to the grazing activities of ostracods and molluscs, and the collapses of cyanobacteria populations in rice fields are closely followed by those of ostracods (Grant et al., 1986). Which ostracod species have the biggest impact on cyanobacteria is currently unknown.

Ostracods have been reported to prey on amphibian eggs and tadpoles, which most animals find unpalatable (Gray et al., 2010; Ottonello and Romano, 2011). This could potentially be another way ostracods affect the rice field environment, as amphibians act as biological controls on rice pests (Khatiwada et al., 2016).

\section{Predators}

Although research has shown that freshwater ostracods and their eggs are consumed by a wide range of groups, either by chance or by groups actively seeking them, the dynamics of predator-prey relationships of ostracods in rice fields are unresolved. Generally, their main predators are fish, waterfowl, amphibians, insect larvae (notably dragonfly and damselfly), backswimmers, and water mites 
(Lowndes, 1930; Proctor, 1964; Lilly et al., 1978; Vinyard, 1979; Allen and Wootton, 1984; Proctor and Pritchard, 1989; Griffiths et al., 1993; Uiblein et al., 1994; Lopez et al., 2002; Blanco et al., 2004; Ghioca-Robrecht and Smith, 2008; Brochet et al., 2010; Vandekerhove et al., 2012), all common in rice field ecosystems. The hard, calcified carapace of ostracods can reduce predation considerably in some cases. In experiments $26 \%$ of individuals of Cypridopsis vidua survived passage through the guts of bluegill sunfish (Lepomis macrochirus Rafinesque, 1810) (Vinyard, 1979), and instars and eggs have also been reported to survive consumption by waterfowl, fish, tadpoles, frogs and flatworms in a similar manner (Lowndes, 1930; Proctor and Malone, 1965; Kornicker and Sohn, 1971; Lopez et al., 2002; Smith and Kamiya, 2008). Populations dynamics can directly affect the prey/predator relationship of ostracods. In experiments with freshwater fish fry and ostracods, it was noted that the fry eat the ostracods, but if the number of ostracods is large, the ostracods attack and eat the fish fry, leaving only the vertebrae and scales (Liperovskaya, 1948). Modernization of rice production has negatively affected some of the predators of ostracods, such as fish and frogs (Katayama et al., 2015).

\section{Survival strategies in rice fields}

Ostracod instars, while physiologically aquatic organisms that extract oxygen from water for respiration, are nonetheless able to tolerate periods of water scarcity by closing their carapaces and waiting for conditions to improve. Adults and juveniles have been reported to enter a torpid state in undersaturated environments, and regain mobility when sufficient moisture is available (Delorme and Donald, 1969; Forester, 1991; Horne, 1993). How im- portant the torpidity strategy is to annually colonizing rice fields is unknown, but experiments have shown that one pond-dwelling species can survive in a torpid state for over a year in soil with a water moisture content as low as 4 to $5 \%$ (Horne, 1993).

Species of the family Cyprididae have desiccation-resistant eggs (Fig. 3), which can survive the fallow, dry periods of rice cultivation (at least for two years), hatching soon after the rice fields are flooded (Stenert et al., 2010). Heterocypris incongruens, a very common inhabitant of rice fields, produces two types of eggs, one of which rapidly develops, and the other which remains dormant $(85 \%$ of the total) (Angell and Hancock, 1989). Heterocypris incongruens eggs can remain viable after drying, exposure to temperatures of between $-25^{\circ} \mathrm{C}$ and $40^{\circ} \mathrm{C}$, and low pressures (Sohn and Kornicker, 1979; Angell and Hancock, 1989). Data concerning the durability of other species' eggs is lacking, but considering the high diversity of Cyprididae in rice field habitats ( $78 \%$ of all rice field species reported; see below and checklist), desiccation-resistant eggs are probably a significant factor in the dominance of this family in rice fields. A study on the effects of straw burning on resting egg banks in Thai rice fields noted that burning has a substantial negative effect on zooplankton abundance and diversity (Chittapun, 2011). Ostracods were included in the study, and unlike other groups they hatched from all burnt samples. The ostracods were not identified below class level, so it is not clear how straw burning affects ostracod diversity, but it indicates that ostracod eggs of at least one species can survive the high temperatures generated during straw burning. Desiccation-resistant eggs are not unequivocally known to exist in other families, but evidence of other ostracod taxa surviving in temporary habitats suggest
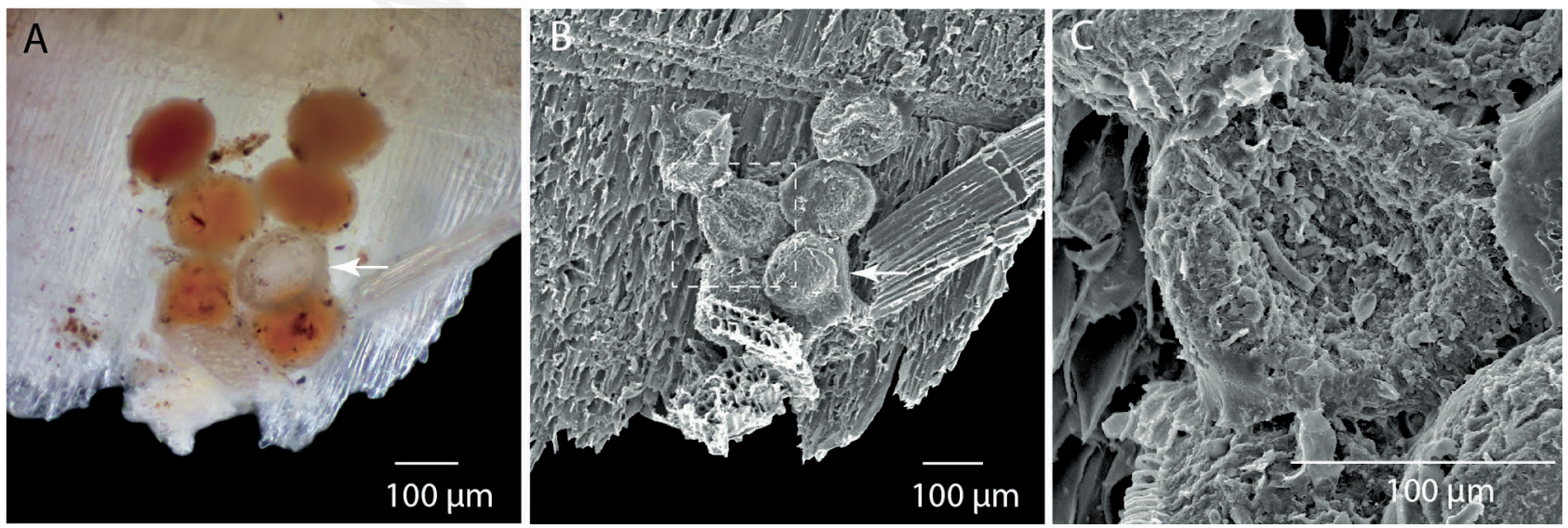

Fig. 3. A) A clutch of eggs of Heterocypris incongruens, attached to a small piece of wood. One egg has hatched (marked with arrow). Light microscopy, eggs submerged under water. B) The same eggs as in A, air dried, splutter coated with gold and photographed with a JEOL 5800 LV scanning electron microscope (arrow marks hatched egg). C) Detail of B, location marked by dotted square on B, showing the outer coating of the egg. 
that they too can have drought-resistant stages (e.g., limnocytherid ostracods: Martens, 1996; Eagar, 2000; Smith and Horne, 2004).

\section{Long term changes in rice field ostracod faunas}

Only one study has compared rice field ostracod faunas between two time periods in the same region; Rossi et al. (2003) compared the rice field ostracod fauna collected in the 1990s with that collected in the 1960s and reported by McKenzie and Moroni (1986) from the same region in Italy. This showed a decline in diversity from 46 to 25 species between the two-time periods spanning 30 years. The faunal composition was also somewhat different, in that six species found in the 1990s were not recorded in rice fields during the 1960s. In Japan, one species previously reported in the $1940-70$ s as being a regular inhabitant in Japanese rice fields during the spring and summer, Notodromas trulla Smith and Kamiya 2014, is now very rare in such habitats (Okubo, 2003; Smith and Kamiya, 2014).

\section{EFFECTS OF PESTICIDES ON RICE FIELD OSTRACODS}

Ostracods can be targeted by pesticide application due to their deleterious effect on nitrogen-fixing cyanobacteria, or be affected by applications that target other taxa. Pesticides developed in the 1950s and 60s and which were used on rice fields were generally more potent and environmentally damaging than recent counterparts (Katayama et al., 2015). Rossi et al. (2003) suggested that the widespread use of pesticides during the 1960s onwards in Italian rice fields was the cause of the decline of ostracod diversity over a thirty-year period. The decline of the Japanese species Notodromas trulla, which used to be common in rice fields during the 1940 s to 70 s, is also perhaps related to pesticide use in conjunction with loss of suitable habitats surrounding rice fields (Okubo, 2003). Studies carried out on pesticides and ostracods in rice fields are relatively sparse, and cover only a handful of identified species. Ostracods have been reported to be highly sensitive to some pesticides and resilient to others (Daam et al., 2013; Grant et al., 1983b; Jolly Thomas and Tessy, 2014; Lim and Wong, 1986; Roger and Watanabe, 1982; Sánchez-Bayo and Goka, 2006a; Takamura and Yasuno, 1986). The responses of different species of ostracods to the same pesticides can also differ. Experiments with carbofuran and lindane on two species of rice field ostracods, Heterocypris carolinensis and Heterocypris luzonensis Neale, 1981, found that the latter species was significantly more tolerant than the former to both pesticides (Grant et al., 1983b). After application of fipronil on an experimental rice field, the ostracod Stenocypris sp. significantly increased in abundance, while Ilyocypris sp. and
Heterocypris sp. decreased (Hayasaka et al., 2012). Different responses to pesticides may be related to resistance acquired by previous exposure (Grant et al., 1983b), but on the other hand, the cumulative ecological impacts of successive treatments of pesticides can negatively affect aquatic faunas, including ostracods (Hayasaka et al., 2012; SánchezBayo, 2014). Although ostracods are generally negatively affected by pesticides directly after application, they can increase their populations substantially soon afterwards to levels higher than before application. This is attributed to their high fecundity, and generally having a higher resistance to pesticides than their predators (e.g., Odonata larvae), and their subsequent increases can inhibit the development of nitrogen-fixing cyanobacteria blooms (Roger, 1996). The seeds of the neem tree (Azadirachta indica), crushed and distributed in rice fields, has been shown to be an effective alternative or supplement to artificial chemical pesticides in controlling ostracods in rice fields (Roger and Watanabe, 1982; Grant et al., 1983c; 1986).

Ostracods have been noted to have lower tolerance than other taxa to imidacloprid, a pesticide widely used in rice fields. One study revealed that Heterocypris incongruens was the most sensitive to imidacloprid of the taxa studied in experimental rice plots (Daam et al., 2013), while another noted that cladocerans can tolerate much higher concentrations than ostracods (Sánchez-Bayo and Goka, 2006b). Environmental impact assessments of imidacloprid are based on toxicity values of the cladoceran Daphnia magna Straus, 1820, a species tolerant to imidacloprid, and therefore fail to address the deleterious environmental impacts of this pesticide on rice field ostracods. Even at nonlethal levels, imidacloprid can impact ostracod survival as it immobilizes them, resulting in retardation of feeding and reproduction, and makes them more vulnerable to predation (Sánchez-Bayo and Goka, 2006b). In rice fields where pesticides such as imidacloprid have significantly reduced the ostracod population, turbidity of the water is lower compared with rice fields with abundant ostracods. This is because ostracods and other meiofauna continuously disturb the soil layer searching for food, increasing turbidity. The lack of meiofauna in rice fields also changes the ecology, allowing Spirogyra algae to bloom, which in turn increases $\mathrm{pH}$ and hampers the growth of weeds (Sánchez-Bayo and Goka, 2006a; Hayasaka et al., 2012).

\section{ORIGIN OF RICE FIELD OSTRACOD FAUNAS}

\section{Asiatic rice}

Common wild rice Oryza rufipogon, the ancestor to asiatic rice (Oryza sativa), is an aquatic plant adapted to subtropical and tropical climates (Higham and Lu, 1998). It is still found, albeit rarely, in the Yangtze Valley of China, where domestication of rice is thought to have first oc- 
curred $~ 8200-13,500$ years ago (Higham and $\mathrm{Lu}, 1998$; Molina et al., 2011). It was wetlands containing wild rice along the Yangtze Valley that were first modified into rice fields, and it is possible that the ostracod fauna of these wetlands were the originators of the first rice field ostracod faunas. Unfortunately, the ostracod faunas of marshes and rice fields in China are very poorly known, so little can be said about the ecology and taxonomy of what these initial faunas were. From the Yangtze Valley, rice farming slowly spread through other parts of China, principally along river valleys, over thousands of years, finally becoming well-established in many areas of Asia by the Iron Age (Fuller et al., 2011). From Asia, rice was introduced to Central Asia, Greece and Sicily maybe as early as $344 \mathrm{BC}$ and finally around other areas of southern Europe (GRiSP, 2013). Rice was transported to South and North America a few hundred years ago, and to Australia in the 19th century (GRiSP, 2013; Lewis, 2012), and the exploitation of rice fields by ostracod in these areas is therefore considerably later than in Asia. Floodplains and low-lying areas along river valleys were first to be converted to rice farming (Fuller et al., 2011), and presumably the native faunas of these areas contributed to the rice field ostracod faunas. The rice fields of Europe, the Americas and Australia are more isolated than those of Asia, and the potential for continuous exchange of species between these and other rice-growing areas must be significantly lower.

\section{African rice}

The second species of domesticated rice, African rice (Oryza glaberrima), originated from the wild species Oryza barthii on the floodplains of the Niger River 2000 $\sim 3000$ years ago (Linares, 2002). African rice has been replaced in much of West Africa by Asian rice, which was introduced by Europeans hundreds of years ago, but African rice is still grown in some areas (Linares, 2002). Information about non-marine ostracods in West Africa is sparse, and no details of rice field ostracods are available from this region. Considering the high endemism of nonmarine ostracods to zoogeographical provinces (93\% for Africa; Martens et al., 2008), the original ostracod faunas of African rice fields are expected to be considerably different from Asian counterparts. Of the two species so far reported from African rice fields (from Madagascar), both are endemic to the Afrotropical zoogeographical province, with one of them endemic to Madagascar (Müller, 1898; Martens, 1986). Influences on the fauna by the introduction of Asian rice are also to be expected, but cannot at present be assessed due to lack of data.

\section{Invasive ostracod species in rice fields}

Rice field faunas are generally considered to be opportunistic species that are tolerant to drastic environmen- tal changes, and which can rapidly colonize rice fields from nearby habitats (Fernando, 1996; Bambaradeniya and Amarasinghe, 2003). It has been noted that rice fields in temperate regions have a tendency to be colonized by a high percentage of tropical and subtropical species (Petkovski, 1964; Fox, 1965; Ghetti, 1973; Martens and Toguebaye, 1985). The high-water temperatures of rice fields in the summer allows these species to survive in temperate regions, and they can thus act as tropical enclaves (Moroni, 1961). In contrast, in tropical regions the ostracod faunas of rice fields are mainly dependent on the faunal composition of surrounding ecosystems (Victor and Fernando, 1980).

Throughout the thousands of years since rice was first domesticated (Molina et al., 2011), faunas have probably been passively dispersed along with the expansion of rice cultivation. Consequently, invasive species in rice fields are likely a phenomenon nearly as old as rice domestication itself. As rice cultivation spread, the number and range of invasive species likely increased too. Invasive species can move in any direction, and it is possible that native species in areas newly farmed for rice became dispersed to older rice-growing regions.

Increasing modernization and movement of people and goods around the world have increased the likelihood of invasive species, and they are currently considered to be one of the greatest ecological and economical threats to the planet (McNeely et al., 2001). Because rice fields are susceptible to colonization by aquatic alien species, they can be seen as invasive stepping-stones, from which alien species can spread to other nearby habitats (Valls et al., 2014). Some ostracod species found in Lake Biwa, an ancient lake in central Japan, may be regularly washed into the lake from surrounding rice fields rather than be permanent residents of the lake (Smith et al., 2011). Some ostracod taxa are particularly prone to passive dispersal due to the desiccation-resistant nature of their eggs (McKenzie and Moroni, 1986), which have the ability to survive passage through the guts of fish and waterfowl (Proctor, 1964). Parthenogenetic reproduction, common in freshwater ostracods, also facilitates their dispersal, with only one egg required to start a new population.

Considering the potential threats to human food supply of invasive species, the identification of such species is paramount. McKenzie and Moroni (1986) coined the Italian term ospiti esteri (foreign guests) to refer to parthenogenetic ostracod species that are only known from rice fields in Italy while known to be native elsewhere. They listed 14 ospiti esteri species (six identified to the species level), out of a total of 53 species found in Italian rice fields, with origins in South America, Asia, Africa, and Australia: Chlamydotheca incisa (Claus, 1892), Dolerocypris sinensis Sars, 1903, Tanycypris pellucida (Klie, 1932), Strandesia (3 spp.), Stenocypris 
major (Baird, 1859), Ilyodromus viridulus (Brady, 1886), Isocypris (2 spp.), Notodromas persica Gurney, 1921, Cypretta (3 spp.). McKenzie and Moroni (1986) backed up their claim by noting that none of their ospiti esteri have been found in fossil studies conducted in Italy. Baltanás (1992) later questioned if the Isocypris species were truly ospiti esteri, due to a lack of data on the distributions of the species known. Additionally, Dolerocypris sinensis is well-established around the Mediterranean, and males are unknown everywhere (Meisch, 2000), so it may not be invasive in Italy. Notodromas persica is also wellknown around the Mediterranean, and because it reproduces sexually, it does not fit the definition of ospiti esteri provided by McKenzie and Moroni (1986).

Five ostracod species are considered to be tropical exotics in the rice field fauna of the Iberian Peninsula: Tanycypris sp., Cypris subglobosa Sowerby, 1840, Dolerocypris sinensis, Stenocypris major and Fabaeformiscandona subacuta (Yang, 1982) (Baltanás ,1992; Escrivà et al., 2012). Due to the Mediterranean climate, small temporary water bodies don't exist during the summer months on the Iberian Peninsula, but the artificial aquatic regime of rice fields provide shallow, high temperature waters during the summer months for these tropical and subtropical species to maintain viable populations (Baltanás, 1992).

Neale (1977) proposed that five species of ostracods (Pseudocypretta maculata Klie, 1932, Hemicypris pyxidata (Moniez, 1892), Strandesia marmorata (Brady, 1886), Strandesia purpurascens (Brady, 1886) and $S$. weirzejskii Tressler, 1937) found in rice fields in the central and southern parts of Sri Lanka were invasive from Indonesia, then known to be the only place where these species also occur. Since then, three of these species, Pseudocypretta maculata, Hemicypris pyxidata, and Strandesia purpurascens, have been reported from India (see checklist of Indian species by Karuthapandi et al., 2014), so the likelihood that they are invasive in Sri Lanka has diminished somewhat.

McKenzie and Moroni (1986) argued that their ospiti esteri were most likely to have been introduced into Italian rice fields via human activities, particularly the movement of agricultural plants and seeds. They discounted alternative scenarios such as wind transport (which is unlikely to have blown ostracod eggs only into rice fields and no other Italian habitats), fish (absent from Italian rice fields), or birds (intercontinental bird transport from Australia and South America deemed unlikely). They also highlighted that it may not just be rice, but the movement of other crops into Italy over a long-time period that contributed to the modern Italian rice field fauna. Other authors have also posited human activities to explain the constituents of the ostracod faunas in rice fields (Fox, 1965; Moroni, 1967; McKenzie, 1971; Neale, 1977). Vic- tor and Fernando (1980), while accepting that exchange of rice plants may play a role, envisaged a variety of passive dispersal mechanisms to explain the rice field faunas of South East Asia.

\section{SUMMARY OF THE CHECKLIST OF RICE FIELD OSTRACODS}

A total of 192 named species and subspecies of ostracods from 26 countries and sovereign states have been reported from rice fields in the published scientific literature (Fig. 1, Appendix). This represents about $7.6 \%$ of all non-marine species. Many other reports have noted the presence of ostracods in rice fields, but the species were not identified, and in many cases not even the superfamily noted, and hence these were not included in the checklist. In some instances, it is unclear which species were recovered from rice fields. Kim and Min (1991a, 1991b) reported eight species of freshwater ostracods from South Korea, stating that most of them occurred in rice fields, but without giving further details. It is therefore unclear which of these eight species were inhabiting rice fields, and which were not, so these records are not included. Note, however, that all of the eight species are known from rice fields elsewhere, and one species, Cyprinotus uenoi Brehm, 1936, was later reported from rice fields in Korea (Chang et al., 2012). Sars (1903) reported seven ostracod species (five of which were new) from China, noting in the introduction that his Chinese samples were partly from fish ponds, partly from rice fields, but he did not specify which species were from which habitat. All seven species were later reported from rice fields elsewhere, but Sars' records are not included in the checklist. Considering the immense amount of research conducted on rice, there are undoubtedly many further records of rice field ostracods in the grey literature (e.g., governmental, and company reports, student theses, etc.), but as these are often not widely available, or known to the wider scientific community, they cannot be included.

Some species are probably accidental occurrences in rice fields [e.g., Candona candida (O. F. Müller, 1776)], likely via irrigation (see Savatenalinton and Suttajit, 2016), and may not be able to establish themselves in this type of habitat in the long term. For other species rice fields are probably an important habitat for them to exploit, and may even be their main habitat in particular regions. For example, in Japan Hemicypris vulgaris Okubo, 1990 has so far only been reported from rice fields (Okubo, 2004). Due to lack of data, it is not clear which category most species belong to, but such data is important in understanding the ecological requirements of ostracods and their potential impacts on the rice field ecosystem. 
Of the 116 countries and states that produce rice worldwide, named ostracods species have been reported for only 26 , representing $22.4 \%$ of the total. For countries and states for which data is available, biodiversity is clearly under-reported in most cases.

\section{Taxonomy}

Seventy eight percent of the species reported from rice fields belong to the family Cyprididae (Fig. 4A, Tab. 1). This is the largest family of non-marine ostracods, containing approximately 1086 described species, representing $43.2 \%$ of all described non-marine species (Tab. 1). Thus, rice fields harbour a proportionally high diversity of Cyprididae species. The next most diverse family found in rice fields is the Candonidae, at $8.3 \%$, a family that accounts for $29.5 \%$ of all described non-marine species, so is under-represented in this habitat. The Ilyocyprididae form $6.3 \%$ of the rice field fauna, but only account for $1.7 \%$ of all described non-marine species, and thus is over-represented in this habitat. The low diversity of Limnocytheridae found in rice fields $(2.1 \%)$ is proportionally less than their diversity in non-marine habitats generally (7.4\%) (Tab. 1). Nine families (eight of which are in the Superfamily Cytheroidea) found in non-marine habitats have not been reported from rice fields (Tab. 1). Some of these may be found in rice fields in the future, while others are primarily brackish water groups and are unlikely to occur in rice fields. Within the family Cyprididae, the most diverse subfamilies are the Cypricercinae (38 species, $25.3 \%$ of total of rice field species), the Herpetocypridinae (30 species, 20\%) and the Cyprinotinae (29 species, 19.3\%) (Fig. 4A).

\section{Taxonomic discrepancies}

Moroni (1967) illustrated some of the species found in Italian rice fields, including Tanycypris pellucida (Klie, 1932) (as Dolerocypris pellucida). Forty-seven years later, Nagler et al. (2014) re-investigated Klie's (1932) original material using scanning electron microscopy. This revealed quite a different carapace shape to that figured in Moroni (1967), and the specimens are therefore unlikely to be conspecific. Other previous identifications of T. pellucida from Japan (namely Okubo, 1990b; 2004; Okubo and Ida, 1989) were also found to be misidentifications, in this case of Tanycypris alfonsi (Nagler et al., 2014; Smith et al., 2014). Misidentifications of rice field species are undoubtedly in the literature, but as species are often not illustrated of figured, it is not clear to what extent this problem exists.

In addition to misidentifications, some previous synonymies are also problematic. The North East Asian species Cyprinotus uenoi was considered to be a junior synonym of the Australian species Cyprinotus cingalensis Brady, 1886 by Karanovic (2008), but this synonymy was later rejected by Savatenalinton and Suttajit (2016), a view endorsed by the current authors. Due to the past erroneous synonymy of these two species, it is not clear if Cyprinotus cingalensis reported from China (Yu, 2014) is C. cingalensis or C. uenoi. Stenocypris macedonica Petkovski and Meisch, 1996 and Stenocypris bolieki Ferguson, 1962 were both synonymized with Stenocypris intermedia Klie, 1932 by Martens (2001). These synonymies were not universally followed by subsequent authors (Külköylüoglu et al., 2015; Valls et al., 2014). Both S. macedonica and S. bolieki are reported to have long swimming setae on the antennae (Ferguson, 1962;
A

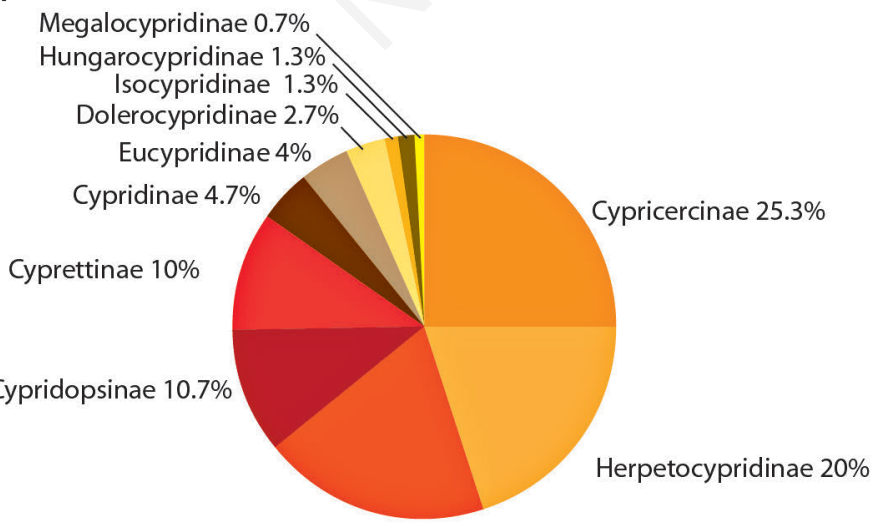

Cyprinotinae $19.3 \%$
B

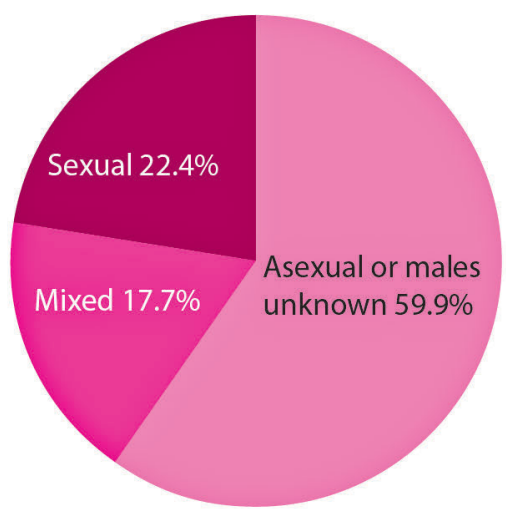

Reproduction Mode - All Species

Fig. 4. A) The proportions of subfamilies in the family Cyprididae reported from rice fields. B) The proportions of reproduction modes of rice field ostracods. 
Petkovski and Meisch, 1996), but these are reduced in $S$. intermedia (Klie, 1932), suggesting that they are not all the same species. Stenocypris bolieki and S. macedonica may be conspecific, but until this can be investigated in more detail, all three species are listed in the checklist. Stenocypris viridis Okubo 1990 and Stenocypris hislopi Ferguson, 1969 are also very similar to $S$. bolieki and $S$. macedonica, and require further taxonomic investigations.

'Cypretta dubia (Daday)' was reported from Italian rice fields by Moroni (1967) and later as 'Cypretta c.f. dubia (Daday 1901)’ by McKenzie and Moroni (1986), and 'Cypretta dubia (Daday 1901)' by Rossi et al. (2003). We could find no other records of this species and it is possibly a misspelling of Cypretta dubiosa (Daday, 1900), which is listed in Moroni (1961).

Victor and Fernando (1980) listed 'Cypridopsis angulata' as occurring in west Malaysia (Tab. 1 of Victor and Fernando 1980), but mention in the text that it was found in rice fields in the Philippines. We could find no other record of this species, and it possibly refers to Plesiocypridopsis angularis (Victor and Michael, 1975).

\section{Reproduction mode}

Freshwater species reproduce sexually, exclusively parthenogenetically, or have mixed reproduction modes, although in the latter case sexual populations tend to be much rarer than asexual ones (e.g., Dolerocypris ikeyai, see Smith, 2011). Twenty two percent (43 species) of the species reported from rice fields are sexually reproducing, and males are commonly found (Fig. 4 B). For another $17.7 \%$ (34 species) males are known, but these species are regionally parthenogenetic; males are only reported from a limited number of localities, and in some instances are rare. These species can be considered to mostly reproduce asexually in rice field habitats. For the rest of the species (115 or 59.9\%), males have not been found, or no data are available about the presence of males.

Most of the posited invasive species in rice fields are parthenogenetic, and McKenzie and Moroni (1986) noted that this form of reproduction was a characteristic of their ospiti esteri. Only one known invasive species of ostracod found in rice fields, Fabaeformiscandona subacuta, reproduces sexually (Smith and Kamiya, 2007; Escrivà et al., 2012). However, this species tends to prefer permanent waterbodies, with rice fields being the only type of temporary water body it is found in (Escrivà et al., 2012). Males have been reported to be extremely rare in rice fields generally (McKenzie and Moroni, 1986), but the checklist for this study has revealed that $22 \%$ of rice field ostracod species reproduce sexually. The almost total ab-

Tab. 1. Number of described living non-marine ostracod species/subspecies in each family globally and represented in rice fields. Global data of free-living non-marine species/subspecies were extracted from Martens et al. (2013), with additional records from Yu et al. (2009) (for China) and updated using published records of recently described species. Entocytheridae (a commensal group on other crustaceans) data were taken from Mestre and Mesquita-Joanes (2013) with marine species (two species) subtracted and some synonymies corrected. Note that some species from lakes listed in Yu et al., (2009) may be subfossils. Data of global species are approximate; an updated checklist of global non-marine ostracod species is in preparation.

\begin{tabular}{|c|c|c|c|c|}
\hline Families & $\begin{array}{c}\text { No. of species } \\
\text { globally }\end{array}$ & $\begin{array}{l}\% \text { of total of } \\
\text { global species }\end{array}$ & $\begin{array}{l}\text { No. of species } \\
\text { in rice fields }\end{array}$ & $\begin{array}{l}\% \text { of total of } \\
\text { rice field species }\end{array}$ \\
\hline Candonidae Kaufmann, 1900 & 742 & 29.5 & 16 & 8.3 \\
\hline Cyprididae Baird, 1845 & 1086 & 43.2 & 150 & 78.1 \\
\hline Cytheridae Baird, 1850 & 16 & 0.6 & 0 & 0 \\
\hline Cytherideidae Sars, 1925 & 109 & 4.3 & 0 & 0 \\
\hline Cytheruridae G.W. Müller, 1894 & 5 & 0.2 & 0 & 0 \\
\hline Darwinulidae Brady \& Robertson, 1885 & 33 & 1.3 & 2 & 1.0 \\
\hline Entocytheridae Hoff, 1942 & 210 & 8.3 & 1 & 0.5 \\
\hline Hemicytheridae Puri, 1953 & 3 & 0.1 & 0 & 0 \\
\hline Ilyocyprididae Kaufmann, 1900 & 43 & 1.7 & 12 & 6.3 \\
\hline Kliellidae Schäfer, 1945 & 2 & 0.1 & 0 & 0 \\
\hline Leptocytheridae Sars, 1925 & 26 & 1.0 & 0 & 0 \\
\hline Limnocytheridae Klie, 1938 & 186 & 7.4 & 4 & 2.1 \\
\hline Loxoconchidae Sars, 1925 & 7 & 0.3 & 0 & 0 \\
\hline Notodromadidae Kaufmann, 1900 & 39 & 1.6 & 7 & 3.6 \\
\hline Terrestricytheridae Schornikov, 1969 & 4 & 0.2 & 0 & 0 \\
\hline Xestoleberidae Sars, 1866 & 5 & 0.2 & 0 & 0 \\
\hline Total & 2516 & 100 & 192 & 100 \\
\hline
\end{tabular}


sence of males in Italian rice fields reported by McKenzie and Moroni (1986) may be a result of the limited area and recent introduction of rice to Italy, which may favour parthenogenetic species over sexual ones.

Martens and Schön (2000) hypothesized that sexual reproduction has an advantage over asexual counterparts in long-lived habitats, such as ancient lakes, and that in temporary and/or young habitats asexual reproduction dominates. Approximately one-fifth of rice field ostracod species reproduce sexually, which is about the same proportion of sexual reproduction in Holocene waterbodies as a whole (asexual species account for $>80 \%$ in Holocene waterbodies according to Martens and Schön, 2000). Thus, rice field ostracods generally appear to mirror those of Holocene waterbodies in terms of reproduction mode despite the more temporary existence of rice field faunas.

\section{CONCLUSIONS AND FUTURE WORK}

Ostracods have a significant impact on the rice field ecosystem and potentially harvests, and therefore are possibly the crustacean group with the largest impact on humans, but their ecological role in rice fields is under appreciated. There is still great urgency in documenting ostracod diversity in rice fields, especially in countries and regions where few or none have been reported so far. Africa, and North and South America, which undoubtedly have very different faunas to Asia, are prime examples, with almost all of these continents' rice field ostracod faunas unknown. In addition, it is crucial to determine the succession of ostracod species through the rice growing season, and establish which species are dominant in rice fields in each region. The ecology of these species needs to be better understood to fully appreciate the impacts that ostracods have on rice. Ostracods can influence the rice field ecosystem in various ways, both positive and negative. They directly affect nutrient recycling through excretion, and indirectly by physically disturbing the soil and releasing minerals, thus improving rice growth. Their grazing on algae such as Spirogyra retards algal blooms, thus stabilizing pH (Sánchez-Bayo and Goka, 2006a). On the other hand, ostracods grazing on nitrogen-fixing cyanobacteria potentially reduce rice yields (Roger, 1996). Not all species of ostracods may have the same types of impacts, depending on food preferences and the timing of appearances during the crop cycle, but without further research this remains unknown. Potentially invasive species in rice fields also need to be identified in order to mitigate possible harmful dispersal from rice fields to surrounding natural habitats. The origin of ostracods in rice fields is extremely poorly known, but due to their high fossilization potential, ostracods could be useful in studies relating to the early domestication of rice. This can only be done within a taxonomic framework of living species, which at present is incomplete or lacking for most regions.

\section{ACKNOWLEDGMENTS}

We thank Alexandre Mestre (University of Valencia) for confirming the numbers of marine entocytherids, and the two anonymous reviewers for their useful suggestions and comments.

\section{REFERENCES}

Allen JRM, Wootton RJ, 1984. Temporal patterns in diet and rate of food consumption of the three-spined stickleback (Gasterosteus aculeatus L.) in Llyn Frongoch, an upland Welsh lake. Freshwater Biol. 14:335-346.

Angell RW, Hancock JW, 1989. Response of eggs of Heterocypris incongruens (Ostracoda) to experimental stress. J. Crust. Biol. 9:381-386.

Baltanás A, 1992. A contribution to the knowledge of the cypridid ostracod fauna (Crustacea, Ostracoda, Cyprididae) on the Iberian Peninsula, and a comparison with adjacent areas. Arch. Hydrobiol. Suppl. 90:419-452.

Bambaradeniya CNB, Amarasinghe FP, 2003. Biodiversity associated with the rice field agroecosystem in Asian countries: A brief review. Working Paper 63. International Water Management Institute, Colombo: $24 \mathrm{pp}$.

Barrion AT, Litsinger JA, 1984. Chironomids, corixids and ostracod pests of irrigated rice seedling roots. Int. Rice Res. Newsl. 9:19.

Blanco S, Romo S, Villena M-J, 2004. Experimental study on the diet of mosquitofish (Gambusia holbrooki) under different ecological conditions in a shallow lake. Int. Rev. Hydrobiol. 89:250-262.

Brochet AL, Gauthier-Clerc M, Guillemain M, Fritz H, Waterkeyn A, Baltanás A, Green AJ, 2010. Field evidence of dispersal of branchiopods, ostracods and bryozoans by teal (Anas crecca) in the Camargue (southern France). Hydrobiologia 637:255-261.

Campbell CE, 1995. The influence of a predatory ostracod, Australocypris insularis, on zooplankton abundance and species composition in a saline lake. Hydrobiologia 302:229-239.

Chang CY, Lee J, Smith RJ, 2012. Nonmarine ostracods (Crustacea) from South Korea, including a description of a new species of Tanycypris Triebel (Cyprididae, Cypricercinae). Zootaxa 3161:1-19.

Chittapun S, 2011. Fire and recovery of resting egg bank:an experimental study in paddy fields in Pathum Thani province, Thailand. Hydrobiologia 662:163-170.

Daam MA, Santos Pereira AC, Silva E, Caetano L, José Cerejeira M, 2013. Preliminary aquatic risk assessment of imidacloprid after application in an experimental rice plot. Ecotox. Environ. Safe. 97:78-85.

De PK, 1939. The role of blue-green algae in nitrogen fixation in rice-fields. P. Roy. Soc. Lond. B. Bio. 127:121-139.

De Deckker P, 1983. Notes on the ecology and distribution of nonmarine ostracods in Australia. Hydrobiologia 106:223-234. 
Delorme LD, Donald D, 1969. Torpidity of freshwater ostracodes. Can. J. Zool. 47:997-999.

Eagar SH, 2000. Freshwater Ostracoda from Tarawa, Kiribati: their implications for dispersal mechanisms. J. Micropalaeontol. 19:68.

Escrivá A, Smith RJ, Aguilar-Alberola JA, Kamiya T, Karanovic I, Rueda J, Schornikov EI, Mesquita-Joanes F, 2012. Global distribution of Fabaeformiscandona subacuta: an exotic invasive Ostracoda on the Iberian Peninsula? J. Crust. Biol. 32:949-961.

Ferguson E, 1962. Stenocypris bolieki, a new freshwater ostracod from Florida and a new record of distribution for the genus. Am. Midl. Nat. 67:65-67.

Fernández-Valiente E, Quesada A, 2004. A shallow water ecosystem rice-fields. The relevance of cyanobacteria in the ecosystem. Limnetica 23:95-108.

Fernando CH, 1996. Ecology of rice fields and its bearing on fisheries and fish culture. p. 217-237. In: S.S. de Silva (ed.), Perspectives in Asian fisheries. Asian Fisheries Society, Manila.

Food and Agriculture Organization of the United Nations Statistics Division (FOASTAT) 2016. http://faostat3.fao.org/home/E

Forés E, Comín FA, 1992. Ricefields, a limnological perspective. Limnetica 10:101-109.

Forester RM, 1991. Ostracode assemblages from springs in the Western United States: Implications for paleohydrology. Mem. Entomol. Soc. Can. 155:181-201.

Fox HM, 1965. Ostracod Crustacea from ricefields in Italy. Mem. Ist. Ital. Idrobiol. 18:205-214.

Fryer G, 1997. The horse-trough ostracod Heterocypris incongruens. Naturalist 122:121-135.

Fuller DQ, van Etten J, Manning K, Castillo C, KingwellBanham E, Weisskopf A, Qin L, Sato Y, Hijmans RJ, 2011. The contribution of rice agriculture and livestock pastoralism to prehistoric methane levels: An archaeological assessment. Holocene 21:743-759.

Ghioca-Robrecht DM, Smith LM, 2008. Feeding ecology of polymorphic larval barred tiger salamanders in playas of the Southern Great Plains. Can. J. Zool. 86:554-563.

Ghetti PF, 1973. [Dynamique de populations d'ostracodes de douse rizieres Italiennes. Notes d'ecologie].[Article in French]. Extr. Ann. Stat. Biol. Besse-en-Chandesse 7:273-294.

Grant IF, Egan EA, Alexander M, 1983a. Measurement of rates of grazing of the ostracod Cyprinotus carolinensis on bluegreen algae. Hydrobiology 106:199-208.

Grant IF, Egan EA, Alexander M, 1983b. Pesticides to control ostracod grazing on blue-green algae. Soil Biol. Biochem. 15:193-197.

Grant IF, Roger PA, Watanabe I, 1985. Effect of grazer regulation and algal inoculation on photodependent nitrogen fixation in a wetland rice field. Biol. Fert. Soils 1:61-72.

Grant IF, Roger PA, Watanabe I, 1986. Ecosystem manipulation for increasing biological N2 fixation by blue-green algae (cyanobacteria) in lowland rice fields. Biol. Agric. Hortic. 3:299-315.

Grant IF, Tirol AC, Aziz T, Watanabe I, 1983c. Regulation of invertebrate grazers as a means to enhance biomass and nitrogen fixation by Cyanophyceae in wetland rice fields. Soil Sci. Soc. Am. J. 47:669-6775.

Gray EP, Nunziata S, Snodgrass JW, Ownby DR, Havel JE,
2010. Predation on green frog eggs (Rana clamitans) by Ostracoda. Copeia 2010:452-456.

Griffiths HI, Martin DS, Shine AJ, Evans JG, 1993. The ostracod fauna (Crustacea, Ostracoda) of the profundal benthos of Loch Ness. Hydrobiologia 254:111-117.

GRiSP (Global Rice Science Partnership), 2013. Rice almanac, 4th edition. International Rice Research Institute, Los Baños: 283 pp.

Hayasaka D, Korenaga T, Suzuki K, Saito F, Sánchez-Bayo F, Goka K, 2012. Cumulative ecological impacts of two successive annual treatments of imidacloprid and fipronil on aquatic communities of paddy mesocosms. Ecotox. Environ. Safe. 80:355-362.

Higham C, Lu TLD, 1998. The origins and dispersal of rice cultivation. Antiquity 72:867-877.

Horne DJ, Martens K, 1998. An assessment of the importance of resting eggs for the evolutionary success of Mesozoic non-marine cypridoidean Ostracoda (Crustacea). Arch. Hydrobiol. 52:549-561.

Horne FR, 1993. Survival strategy to escape desiccation in a freshwater ostracod. Crustaceana 65:53-61.

Hou Y, Ho J, Ye C, 1978. [The Cretaceous-Tertiary ostracods from the marginal region of the Yangtze-Han River plain in central Hubei].[Article in Chinese with English abstract]. Mem. Nanjing Inst. Geol. Palaeo. Acad. Sinica 9:130-206.

Huang B, 1984. [Quaternary Ostracods from Qinghai Lake region].[Article in Chinese with English abstract]. Bull. Nanjing Inst. Geol. Palaeo. Acad. Sinica 7:187-236.

Jolly Thomas V, Tessy KL, 2014. The Effect of various pesticides Carbofuran, Cardendezine, Lindane, Fenvalerate, Nuvacron, Neembicidine on the Ostracod, Oncocypris pustulosa. Scitech J. 1:15-18.

Karanovic I, 2008. Three interesting Cyprididae (Ostracoda) from Western Australia. Rec. West. Austral. Mus. 24:267-287.

Karuthapandi M, Rao DV, Xavier Innocent B, 2014. Freshwater Ostracoda (Crustacea) of India - a checklist. J. Threat. Taxa 6:6576-6581.

Katayama N, Baba YG, Kusumoto Y, Tanaka K, 2015. A review of post-war changes in rice farming and biodiversity in Japan. Agric. Syst. 132:73-84.

Khatiwada JR, Ghimire S, Khatiwada SP, Paudel B, Bischof R, Jiang J, Haugaasen T, 2016. Frogs as potential biological control agents in the rice fields of Chitwan, Nepal. Agric. Ecosyst. Environ. 230:307-314.

Kim W, Min GS, 1991a. Redescription of recent freshwater ostracods (Crustacea: Ostracoda) from Korea. New Zeal. J. Zool. 34:307-322.

Kim W, Min GS, 1991b. Redescription of recent freshwater ostracods (Crustacea: Ostracoda) from Korea: A systematic study of four species of family Cyprididae. Kor. J. Syst. Zool. 7:81-99.

Klie W, 1932. [Die Ostracoden der Deutschen Limnologischen Sunds-Expedition].[Article in German]. Arch. Hydrobiol. Supp. 11:447-502.

Kornicker LS, Sohn IG, 1971. Viability of ostracode eggs egested by fish and and effect of digestive fluids on ostracode shells - ecological and paleoecologic implications, p. 125-135. In: H.J. Oertli (ed.), Paléoécologie Ostracodes Pau 1970. Bulletin Centre de Recherches Pau - SNPA, 5 Supplement.

Khush GS, 1984. Terminology for rice growing environments, 
p. 5-10. In: International Rice Research Institute (IRRI) (ed.), Terminology for rice growing ecosystems. Manila.

Külköylüoglu O, Akdemir D, Yavuzatmaca M, Yilmaz O, 2015. A checklist of recent non-marine Ostracoda (Crustacea) of Turkey with three new records. Rev. Hydrobiol. 8:77-90.

Linares OF, 2002. African rice (Oryza glaberrima): History and future potential. P. Natl. Acad. Sci. USA. 99:16360-16365.

Lewis G, 2012. 'The Growers' Paddy', Land, Water and Cooperation in the Australian Rice Industry to the 1990s. e-book. Available from: http://sydney.edu.au/business/_data/assets/pdf_file/0008/155969/Lewis-GrowersPaddy-2012.pdf

Lilly CK, Ashley DL, Tarter DC, 1978. Observations on a population of Sialis itasca Ross in West Virginia (Megaloptera: Sialidae). Psyche 85:209-218.

Lim RP, Wong MC, 1986. The effects of pesticides on the population dynamics and production of Stenocypris major Baird (Ostracoda) in ricefields. Arch. Hydrobiol. 106:421-427.

Liperovskaya ES, 1948. [On the feeding of freshwater ostracods].[Article in Russian]. Zool. Zh. 27:125-136.

Lopez LCS, Gonçalves DA, Mantovani A, Rios RI, 2002. Bromeliad ostracods pass through amphibian (Scinax perpusillus) and mammalian guts alive. Hydrobiologia 485:209-211.

Lowndes AG, 1930. Living ostracods in the rectum of a frog. Nature 126:958.

Maclean JL, Dawe DC, Hardy B, Hettel GP, 2002. Rice almanac. Source book for the most important economic activity on Earth. CABI Publishing, Wallingford: 253 pp.

Martens K, 1986. Taxonomic revision of the subfamily Megalocypridinae Rome, 1965 (Crustacea, Ostracoda). Verhand. k. Acad. Wetensch. Lett. Schone Kunsten K1. Wetensch. 48:4-139.

Martens K, 1996. On Korannacythere gen. nov. (Crustacea, Ostracoda), a new genus of temporary pool limnocytherids from southern Africa, with the description of three new species and a generic reassessment of the Limnocytherinae. Bull. K. Belg. Inst. Natuurwetensch. Biol. 66:51-72.

Martens K, 2001. Taxonomy of the Herpetocypridinae (Ostracoda, Cyprididae). Crustaceana 74:295-308.

Martens K, Savatenalinton S, Schön I, Meisch C, Horne DJ, 2013. World checklist of freshwater Ostracoda species. Accessed on: 19 May 2016. Available from: http://fada.biodiversity.be/group/show/18

Martens K, Schön I, 2000. The importance of habitat stability for the prevalence of sexual reproduction, p. 324-330. In: K. Minoura (ed.), Lake Baikal, a mirror in time and species for understanding global change processes. Elsevier, Amsterdam.

Martens K, Schön I, Meisch C, Horne DJ, 2008. Global diversity of ostracods (Ostracoda, Crustacea) in freshwater. Hydrobiologia 595:185-193.

Martens K, Toguebaye BS, 1985. On the presence of Cypris subglobosa Sowerby, 1840 (Crustacea, Ostracoda) in Africa, with notes on the distribution of this species. Ann. Soc. Roy. Zool. Belg. 115:147-153.

McKenzie KG, 1971. Palaeozoogeography of fresh-water Ostracoda, p. 207-237. In: H.J. Oertli (ed.) Paléoécologie Ostracodes Pau 1970. Bulletin Centre de Recherches Pau SNPA, 5 Supplement.

McKenzie KG, Moroni A, 1986. Man as an agent of crustacean passive dispersal via useful plants - exemplified by Ostracoda ospiti esteri of the Italian ricefields ecosystem - and implications arising therefrom. J. Crust. Biol. 6:181-198.

McNeely JA, Mooney HA, Neville LE, Schei P, Waage JK, 2001. A global strategy on invasive alien species. IUCN Gland: 50 pp.

Meisch C, 2000. Freshwater Ostracoda of Western and Central Europe. Suißwasserfauna von Mitteleuropa 8/3. Spektrum Akademischer Verlag, Heidelberg: 522 pp.

Mestre A, Mesquita-Joanes F, 2013. Entocytheridae (Ostracoda) World Database. Accessed on 7 March 2017. Available from: http://www.gbif.es/ipt/resource?r=entocytheridae

Miao W, 2010. Recent developments in rice-fish culture in China: a holistic approach for livelihood improvement in rural areas, p. 15-40. In: S.S. De Silva and F. B. Davy (eds.), Success stories in Asian aquaculture. Springer.

Mischke S, Bößneck U, Diekmann B, Herzschuh U, Jin HJ, Kramer A, Wünnemann B, Zhang CJ, 2010. Quantitative relationship between water-depth and sub-fossil ostracod assemblages in Lake Donggi Cona, Qinghai Province, China. J. Paleolimn. 43:589-608.

Mischke S, Herzschuh U, Massmann G, Zhang CJ, 2007. An ostracod-conductivity transfer function for Tibetan lakes. J. Paleolimn. 38:509-524.

Mischke S, Wünnemann B, 2006. The Holocene salinity history of Bosten Lake (Xinjiang, China) inferred from ostracod species assemblages and shell chemistry: Possible palaeoclimatic implications. Quat. Inter. 154-155:100-112.

Molina J, Sikora M, Garud N, Flowers JM, Rubinstein S, Reynolds A, Huang P, Jackson S, Schaal BA, Bustamante CD, Boyko AR, Purugganan MD, 2011. Molecular evidence for a single evolutionary origin of domesticated rice. P. Natl. Acad. Sci. USA. 108:8351-8356.

Moroni A, 1961. [L'ecosistema di risaia].[Article in Italian]. Ann. Fac. Agraria Univ. Cattolica Sacro Cuore 1:490-624.

Moroni A, 1967. [Ostracodi delle risaie italiane. Sistematica, ecologia distribuzione geografica].[Book in Italian]. Ed. Studium Parmense, Parma: 79 pp.

Müller GW, 1898. [Die Ostracoden].[Article in German]. Abhandl. Senckenb. naturf. Ges. 21:257-296.

Nagler C, Geist J, Matzke-Karasz R, 2014. Revision of the genus Tanycypris (Ostracoda, Cypricercinae) with the description of Tanycypris alfonsi $\mathrm{n}$. sp., and an identification key to the genus. Zootaxa 3821:401-424.

Neale JW, 1977. Ostracods from the rice-fields of Sri Lanka (Ceylon), p. 271-283. In: H. Löffler and D.L. Danielopol (eds.), Aspects of Ecology and zoogeography of recent and fossil ostracods. Junk Publishers, The Hague.

Okubo I, 1972a. Freshwater Ostracoda from Japan, I. Two species of the genus Dolerocypris Kaufmann, 1900. Rev. Shujitsu Jr. Coll. Okayama 1:41-60.

Okubo I, 1972b. Freshwater Ostracoda from Japan, II. Cypris subglobosa Sowerby, 1840. Rev. Shujitsu Jr. Coll. Okayama 1:61-72.

Okubo I, 1972c. Freshwater Ostracoda from Japan, IV. Heterocypris incongruens (Ramdohr, 1808). Rev. Shujitsu Jr. Coll. Okayama 1:73-84.

Okubo I, 1972d. Strandesia camaguinensis Tressler, 1937, from Japan (Ostracoda, Cyprididae). P. Jpn. Soc. Syst. Zool. 8:9-14.

Okubo I, 1973a. Cypretta seurati Gauthier, 1929, from Japan (Ostracoda, Cyprididae). P. Jpn. Soc. Syst. Zool. 9:1-6. 
Okubo I, 1973b. Heterocypris takedai sp. nov. (Ostracoda, Cyprididae) from Japan. Annot. Zool. Japon. 46:85-89.

Okubo I, 1974a. Chrissia vittata sp. nov. from Japan (Ostracoda, Cyprididae). P. Jpn. Soc. Syst. Zool. 10:1-9.

Okubo I, 1974b. Two species of the genus Cyprinotus (Ostracoda, Cyprididae) from Japan. Res. Crust. 6:58-70.

Okubo I, 1975. Stenocypris major (Baird, 1859) from Japan. Bull. Biogeog. Soc. Jpn. 31:1-6.

Okubo I, 1990a. Seven new species of freshwater Ostracoda from Japan. Res. Crust. 19:1-12.

Okubo I, 1990b. Sixteen species of freshwater Ostracoda from Japan. Bull. Biogeog. Soc. Jpn 45:39-50.

Okubo I, 2003. [The freshwater ostracod Notodromas monacha (O. F. Muiller, 1776)].[Article in Japanese]. Bull. Biogeog. Soc. Jpn. 58:43-48.

Okubo I, 2004. [Nihon tansui san kaimijinko rui ni tsuite].[Book in Japanese]. Kabushikigaisha Sanmon Insatsusho, Okayama: 72 pp.

Okubo I, Ida K, 1989. [Freshwater Ostracoda from Gunma Prefecture, Japan].[Article in Japanese]. Bull. Biogeog. Soc. Japan 44:105-107.

Osa-Afiana LO, Alexander M, 1981. Factors affecting predation by a microcrustacean (Cypris sp.) on nitrogen-fixing bluegreen algae. Soil Biol. Biochem. 13:27-32.

Ottonello D, Romano A, 2011. Ostracoda and Amphibia in temporary ponds: who is the prey? Unexpected trophic relation in a Mediterranean freshwater habitat. Aqua. Ecol. 45:55-62.

Petkovski TK, 1964. [Bemerkenswerte Entomostraken aus Jugoslavien].[Article in German]. Mus. Macedonici Sci. Nat. 9:147-181.

Petkovski TK, Meisch C, 1996. Species of the genus Stenocypris Sars, 1889 from the rice-fields of FYR Macedonia (Crustacea, Ostracoda). Trav. Sci. Mus. Hist. Nat. Luxemb. 23:57-85.

Proctor H, Pritchard G, 1989. Neglected predators: water mites (Acari: Parasitengona: Hydrachnellae) in Freshwater Communities. J. N. Am. Benthol. Soc. 8:100-111.

Proctor VW, 1964. Viability of crustacean eggs recovered from ducks. Ecology 45:656-658.

Proctor VW, Malone CR, 1965. Further evidence of the passive dispersal of small aquatic organisms via the intestinal tract of birds. Ecology 46:728-729.

Roger PA, 1996. Biology and management of the floodwater ecosystem in ricefields. International Rice Research Institute, Manila: $250 \mathrm{pp}$.

Roger PA, Kurihara Y, 1991. Floodwater biology of tropical wetland ricefields, p. 275-300. In: Proceedings of the First International Symposium on Paddy Soil Fertility, ChiangMai, Thailand.

Roger PA, Simpson I, Oficial R, Ardales S, Jimenez R, 1994a. Effects of pesticides on soil and water microflora and mesofauna in wetland ricefields: a summary of current knowledge and extrapolation to temperate environments. Aust. J. Exp. Agr. 34:1057-1068.

Roger PA, Simpson I, Oficial R, Ardales S, Jimenez R, 1994 b. Impact of pesticides on soil and water microflora and fauna in wetland ricefields, p. 255-276. In: P.S. Teng, K.L. Heong, K. and Moody (eds.), Rice pest science and management. Selected papers from the International Rice Research Conference, International Rice Research Institute, Manila, Philippines.
Roger PA, Watanabe I, 1982. Research on algae, blue-green algae, and phototrophic nitrogen fixation at the International Rice Research Institute (1963-81), summarization, problems, and prospects. IRRI Res. Pap. Ser. 78:3-21.

Rossi V, Benassi G, Belletti F, Menozzi P, 2011. Colonization, population dynamics, predatory behaviour and cannibalism in Heterocypris incongruens (Crustacea: Ostracoda). J. Limnol. 70:102-108.

Rossi V, Benassi G, Veneri M, Bellavere C, Menozzi P, Moroni A, McKenzie KG, 2003. Ostracoda of the Italian ricefields thirty years on: a new synthesis and hypothesis. J. Limnol. 62:1-8.

Sánchez-Bayo F, 2014. The trouble with neonicotinoids. Chronic exposure to widely used insecticides kills bees and many other invertebrates. Science 346:806-807.

Sánchez-Bayo F, Goka K, 2006a. Ecological effects of the insecticide imidacloprid and a pollutant from antidandruff shampoo in experimental rice fields. Environ. Toxicol. Chem. 25:1677-1687.

Sánchez-Bayo F, Goka K, 2006b. Influence of light in acute toxicity bioassays of imidacloprid and zinc pyrithione to zooplankton crustaceans. Aquat. Toxicol. 78:262-271.

Sars GO, 1903. Fresh-water Entomostraca from China and Sumatra. Arch. Math. Naturvid. 25:3-44.

Savatenalinton S, Martens K, 2008. Redescription of Hemicypris mizunoi Okubo, 1990 (Crustacea, Ostracoda) from Thailand, with a reassessment of the validity of the genera Hemicypris and Heterocypris. Bull. K. Belg. Inst. Natuurwetensch. Biol. 78:17-27.

Savatenalinton S, Martens K, 2009. Generic revision of Cypricercinae McKenzie, 1971 (Crustacea, Ostracoda), with the description of three new genera and one new species and a phylogenetic analysis of the subfamily. Hydrobiologia 632:1-48.

Savatenalinton S, Martens K, 2010. On the subfamily Cypricercinae McKenzie, 1971 (Crustacea, Ostracoda) from Thailand, with the description of six new species. Zootaxa 2379:1-77.

Savatenalinton S, Suttajit M, 2016. A checklist of Recent nonmarine ostracods (Crustacea: Ostracoda) from Thailand, including descriptions of two new species. Zootaxa 4067:1-34.

Simpson IC, Roger PA, Oficial R, Grant IF, 1994. Effects of nitrogen fertilizer and pesticide management on floodwater ecology in a wetland ricefield. Biol. Fert. Soils 17:138-146.

Smith AJ, Delorme LD, 2010. Ostracoda, p. 725-771. In: J.H. Thorp, A.P. Covich (eds.), Ecology and classification of North American freshwater invertebrates. Elsevier, London.

Smith RJ, 2011. Groundwater, spring and interstitial Ostracoda (Crustacea) from Shiga Prefecture, Japan, including descriptions of three new species and one new genus. Zootaxa 3140:15-37.

Smith RJ, Horne DJ, 2004. The first British record of Paralimnocythere psammophila (Flossner, 1965) (Ostracoda, Cytheroidea, Limnocytheridae). J. Micropalaeo. 23:133-134.

Smith RJ, Janz H, Okubo I, 2011. Recent Cyprididae and Ilyocyprididae (Crustacea: Ostracoda) from Lake Biwa, Japan, including a summary of the lake's ostracod fauna. Zootaxa 2874:1-37.

Smith RJ, Kamiya T, 2007. Copulatory behaviour and sexual morphology of three Fabaeformiscandona Krstic, 1972 (Candoninae, Ostracoda, Crustacea) species from Japan, in- 
cluding descriptions of two new species. Hydrobiologia 585:225-248.

Smith RJ, Kamiya T, 2008. The ontogeny of two species of Darwinuloidea (Ostracoda, Crustacea). Zool. Anz. 247:275-302.

Smith RJ, Kamiya T, 2014. The freshwater ostracod (Crustacea) genus Notodromas Lilljeborg, 1853 (Notodromadidae) from Japan; taxonomy, ecology and lifestyle. Zootaxa 3841:239-256.

Smith RJ, Lee J, Chang CY, 2014. Nonmarine Ostracoda (Crustacea) from Jeju Island, South Korea, including descriptions of two new species. J. Nat. Hist. 49:37-76.

Sohn IG, Kornicker LS, 1979. Viability of freeze-dried eggs of the freshwater Heterocypris incongruens, p. 1-3. In: Serbian Geological Society (ed.), Proceedings of the VII International Symposium on Ostracodes. Taxonomy, biostratigraphy and distribution of ostracodes, Belgrade.

Stenert C, Bacca RC, Ávila AC, Maltchik L, Rocha O, 2010. Do hydrologic regimes used in rice fields compromise the viability of resting stages of aquatic invertebrates? Wetlands 30:989-996.

Strayer D, 1985. The benthic micrometazoans of Mirror Lake, New Hampshire. Arch. Hydrobiol. Supp. 72:287-426.

Takamura K, Yasuno M, 1986. Effects of pesticide applications on chironomid larvae and ostracods in rice fields. Appl. Entomol. Zool. 21:370-376.

Tanaka H, Kotorii H, Yokozawa K, Wakabayashi F, Kimoto K, Sano K, 2015. [Distribution and occurrence of freshwater Ostracoda (Crustacea) from southwest region of Mt. Fuji].[Article in Japanese]. Taxa P. Jpn. Soc. Syst. Zool. 38:26-41.

Taniguchi M, Toyota K, Kimura M, 1997. Epibiotic bacteria associated with microcrustaceans in the overlying water of paddy fields. Soil Sci. Plant Nutr. 43:633-641.

Uiblein F, Roca JR, Danielopol DL, 1994. Experimental observations on the behaviour of the ostracode Cypridopsis vidua. Verh. Internat. Verein Limnol. 25:2418-2420.

Valls L, Rueda J, Mesquita-Joanes F, 2014. Rice fields as facilitators of freshwater invasions in protected wetlands: the case of Ostracoda (Crustacea) in the Albufera Natural Park (E Spain). Zool. Stud. 53:1-10.

Van Arsdale P, Lewis T, 1995. Triple-crop rice farming in Java: Implications for sustainable development. J. Sustain. Agri. 6:5-21.

Van den Broecke L, Martens K, Piere V, Schön I, 2012. Ostracod valves as efficient UV protection. J. Limnol. 71:119-124.

Vandekerhove J, Namiotko T, Hallmann E, Martens K, 2012. Predation by macroinvertebrates on Heterocypris incongruens (Ostracoda) in temporary ponds: impacts and responses. Fund. App. Limnol. 181:39-47.

Victor R, Fernando CH, 1980. Freshwater Ostracoda from the ricefields of South East Asia. Trop. Ecol. Dev. 1980:957-970.

Victor R, Fernando CH, 1981a. Description of a new species of the genus Hungarocypris Vavra, 1906 (Crustacea: Ostracoda) from Sulawesi, Indonesia, with a discussion on the distribution of the genus. Hydrobiologia 77:145-154.

Victor R, Fernando CH, 1981b. Freshwater Ostracoda of the genera Chrissia Hartmann, 1957 and Stenocypris Sars, 1889 from Malaysia, Indonesia and the Philippines. Mitt. Hamb. Zool. Mus. Inst. 78:151-168.

Victor R, Fernando CH, 1981c. Freshwater ostracods (Crus- tacea: Ostracoda) of the genus Cypretta Vavra, 1895 from Malaysia, Indonesia and the Philippines. Int. Revue ges. Hydrobiol. 66:415-433.

Victor R, Fernando CH, 1981d. Freshwater ostracods (Crustacea: Ostracoda) of the genus Strandesia Vavra, 1895 from Malaysia, Indonesia and the Philippines. Arch. Hydrobiol. Supp. 58:469-522.

Victor R, Fernando CH, 1981e. Freshwater ostracods (Crustacea: Ostracoda) of the subfamily Cyprinotinae Bronstein, 1947 from Malaysia, Indonesia and the Philippines. Hydrobiologia 83:11-27.

Victor R, Fernando CH, 1981f. Freshwater otracods (Crustacea: Ostracoda) of the subfamily Dolerocypridinae Triebel, 1961 from Southeast Asia. Zool. J. Linn. Soc. 72:107-116.

Victor R, Fernando CH, 1981g. Redescription of three Cyclocypridinae freshwater ostracods (Crustacea, Ostraoda) from Southeast Asia. J. Nat. Hist. 15:757-768.

Victor R, Fernando CH, 1982. A taxonomic reevaluation of freshwater ostracods (Crustacea, Ostracoda) referred to the genus Cypridopsis Brady, 1868 from Southeast Asia. Hydrobiologia 94:285-291.

Vinyard G, 1979. An ostracod (Cypridopsis vidua) can reduce predation from fish by resisting digestion. Am. Midl. Nat. 102:108-190.

Watanabe I, Roger PA, 1985. Ecology of flooded rice fields, p. 229-243. In: Proceedings of the Workshop on Wetland Soils: Characterisation, Classification, and Utilization. IRRI, Los Baños.

Whatley RC, Bajpai S, Whittaker JE, 2003. The identity of the non-marine ostracod Cypris subglobosa Sowerby from the intertrappean deposits of peninsular India. Palaeontology 46:1281-1296.

Wilson JT, Greene S, Alexander M, 1980. Effect of microcrustaceans on blue-green algae in flooded soil. Soil Biol. Biochem. 12:237-240.

Yamazaki M, Hamada Y, Ibuka T, Momii T, Kimura M, 2001. Seasonal variations in the community structure of aquatic organisms in a paddy field under a long term fertilizer trial. Soil Sci. Plant Nutr. 47:587-599.

Yoshida S, 1981. Fundamentals of rice crop science. The International Rice Research Institute, Los Baños, Laguna, Philippines. 269 pp.

Yu N, 2014. [Non-marine Ostracoda from China].[Book in Chinese]. Shanghai Educational Publishing House: 283 pp.

Yu N, Zhao Q, Li E, Chen S, Chen L, 2009. An updated and annotated checklist of recent nonmarine ostracods from China. Zootaxa 2067:29-50.

Zhai DY, Xiao JL, Zhou L, Wen RL, Chang ZG, Wang X, Jin XD, Pang QQ, Itoh S, 2011. Holocene East Asian monsoon variation inferred from species assemblage and shell chemistry of the ostracodes from Hulun Lake, Inner Mongolia. Quat. Res. 75:512-522.

Zheng S, 1983. [Early Tertiary non-marine ostracodes from Changhe of Cixi, Zhejiang].[In Chinese with English abstract]. Acta Palaeo. Sinica 22:577-581.

Zhu LP, Peng P, Xie MP, Wang JB, Frenzel P, Wrozyna C, Schwalb A, 2010. Ostracod-based environmental reconstruction over the last 8,400 years of Nam Co Lake on the Tibetan plateau. Hydrobiologia 648:157-174. 